\title{
Fibroblastų vaidmuo kvėpavimo takų remodeliacijos vystymuisi sergant astma
}

\author{
THE ROLE OF FIBROBLAST IN DEVELOPMENT OF AIRWAY REMODELING IN ASTHMA
}

\author{
ANDRIUS JANUŠKEVIČIUS ${ }^{1}$, ROKAS STONKUS ${ }^{1}$, IEVA JANULAITYTE் ${ }^{1}$, \\ KĘSTUTIS MALAKAUSKAS ${ }^{1,2}$ \\ ${ }^{1}$ LSMU MA Pulmonologijos klinikos Pulmonologijos laboratorija, ${ }^{2}$ LSMU MA Pulmonologijos klinika
}

\begin{abstract}
Santrauka. Terminu kvépavimo takų remodeliacija apibūdinami struktūriniai plaučiu pokyčiai sergant astma. Fibroblastai yra mezenchiminès lastelès, organizme randamos tiek nekontraktilišku fibroblastu, tiek kontraktiliškumu pasižyminčiu miofibroblastu fenotipuose. Sergant astma, plaučiu fibroblastu skaičius padidèja dèl gausesnio proliferaciją skatinančiu mediatoriu kiekio, intensyvesnio epitelinio-mezenchiminio virsmo bei fibrocitu infiltracijos i kvepavimo takus iš periferinio kraujo. Epitelinis-mezenchiminis virsmas - tai procesas, kurio metu dalis epiteliniu lasteliu igauna mezenchiminèms lastelems büdingu savybiu, o sutrikęs epitelinis-mezenchiminis virsmas nustatomas daugelio plaučiu ligu atvejų. Fibrocitai turi fibroblastu, monocitu ir hematopoetiniu ląsteliu savybiu bei lètinio kvépavimo taku uždegimo fone gali migruoti i sergančiuju astma plaučius ir diferencijuoti i fibroblastus. Gausesne fibroblastu populiacija plaučiuose dèl intensyvesnès proliferacijos, epitelinio-mezenchiminio virsmo ir fibrocitu infiltracijos prisideda prie sutrikusios užlastelinio užpildo baltymu apykaitos bei didesnio įvairiu citokinu, chemokinu bei augimo faktoriu kiekio, taip prisidedant ir prie kvépavimo taku remodelicijos vystymosi sergant astma.

Reikšminiai žodžiai: fibroblastai, kvépavimo takų remodeliacija, fibrocitai, epitelinis-mezenchiminis virsmas, astma.

Summary. Airway remodeling is an important component of the structural changes of airways seen in asthma. Fibroblasts are mesenchymal stem cells found in organism at non-contractile fibroblasts form or at contractility properties having myofibroblasts form. During asthma, lung fibroblasts population is significantly increased due to higher their proliferation ratio and increased epithelial-mesenchymal transition and fibrocytes infiltration into asthmatic lungs from peripheral blood. Epithelial-mesenchymal transition is a process, during which part of epithelial cells takes mesenchymal cells properties and altered epithelial-mesenchymal transition process is determined at various lung diseases. Fibrocytes have fibroblasts, monocytes and hematopoietic stem cells characteristics and during chronic airway inflammation can infiltrate into asthmatic lungs and differentiate into fibroblasts. Increased fibroblasts population at lungs due to increased their proliferation ratio, epithelial-mesenchymal transition and fibrocytes infiltration, contribute to altered extracellular matrix proteins deposition and increased levels of various cytokines, chemokines and growth factors leading to development of airway remodeling in asthma.
\end{abstract}

Key words: fibroblast, airway remodeling, fibrocyte, epithelial-mesenchymal transition, asthma.

\section{IVADAS}

Astma - tai viena labiausiai paplitusių kvépavimo takų ligų visame pasaulyje. Sergant šia liga, lètinis kvėpavimo takų uždegimas lemia padidejjusį bronchų reaktyvumą ir struktūrinius kvèpavimo takų pokyčius, dar vadinamus remodeliacija. Kvėpavimo takų remodeliacija apibūdinama kaip struktūriniai epitelio pokyčiai, subepitelinè fibrozė, padidejjusi bronchų lygiưjų raumenų masè, pakitusi užląstelinio užpildo apykaita, sumažejjęs atstumas tarp bronchų lygiųjų raumenų ir epitelio sluoksnių, kraujagyslių tinklo pokyčiai, edema. Vertinant astmos patofiziologiją, ypatingas dèmesys skiriamas bronchų lygiesiems raumenims ir pastebimiems struktūriniams pokyčiams (padidèjusi masè dèl audinio hiperplazijos ir hipertrofijos), kurie
Ł̇vardijami kaip pagrindiniai simptomus sukeliantys veiksniai sergant astma. Tačiau naujausi tyrimai apima ir plaučių jungiamąji audinị, kartu su svarbiausiomis struktūrinèmis ląstelèmis - fibroblastais, kurie vaidina svarbų vaidmenị astmos patogenezèje.

Plaučių fibroblastų skaičius subepiteliniame sluoksnyje sergant astma patikimai padideja. Manoma, kad tai vyksta dèl žymiai greičiau proliferuojančių fibroblastų bei didesnès ịvairių citokinų, chemokinų ir augimo faktorių koncentracijos plaučiuose. Tačiau yra įrodymų, kad dèl vyraujančio lètinio uždegimo suintensyvejja epitelinis-mezenchiminis virsmas, kurio metu dalis epitelinių ląstelių igauna mezenchiminèms ląstelèms būdingų savybių bei papildo jungiamojo audinio fibroblastų populiaciją. Kitas svarbus veiksnys 


\section{Moksliniai darbai}

yra gausesnis fibrocitų, t. y. iš kaulų čiulpų išskiriamų mezenchiminių kamieninių ląstelių, turinčių tiek hematopeotinèms ląstelèms, monocitams bei fibroblastams būdingų savybių, skaičius periferiniame kraujyje, kurie po atitinkamo stimulo migruoja i kvèpavimo takus bei diferencijuoja į fibroblastų fenotipą. Plaučių fibroblastai, būdami tarpininkais tarp plaučių bronchų lygiųjų raumenų ir epitelio sluoksnių, pasižymi svarbia plaučių audinių homeostazès palaikymo funkcija, o išorinių veiksnių sukelta sutrikusi fibroblastų aktyvacija gali gerokai prisidèti prie kvėpavimo takų remodeliacijos vystymosi sergant astma.

Šiame straipsnyje aptariamas fibroblastų vaidmuo vystantis kvèpavimo takų remodeliacijai sergant astma. Pateikiami naujausi duomenys apie pagrindinius jų šaltinius, išskiriamus mediatorius ir užląstelinio užpildo baltymus bei jų diferenciacijos ị miofibroblastus svarbą astmos patogenezejje.

\section{FIBROBLASTŲ VAIDMUO AUDINIUOSE}

Fibroblastų randama beveik visuose organizmo audiniuose. Remiantis specifinėmis skirtingų audinių ypatybėmis bei galimomis patologinèmis organizmo būsenomis, fibroblastai gali skirtis savo fenotipais, i̊skaitant nekontraktiliškus fibroblastus, kontraktiliškus miofibroblastus bei tarpinius fenotipus, įtraukiant protomiofibroblastus. Fibroblastai yra metaboliškai aktyvios ląstelès, kurios atlieka svarbų vaidmenị, reguliuodamos užląstelinio užpildo sudètị, skysčių kiekį bei slègị audiniuose ir gijimo procesą po audinių struktūros pažeidimų [1]. Fibroblastų skaičius audinyje yra išlaikomas pastovus, tačiau dèl ịvairių priežasčių sutrikdytos proliferacijos jų skaičius gali žymiai padidèti. Pakitusi proliferacija nèra vienintelè priežastis, kitas svarbus aspektas yra epitelio ląstelių virsmas mezenchiminèmis, taip papildant fibroblastų kieki jungiamajame audinyje [2]. Sergant ịvairiomis ligomis, įskaitant ir plaučių ligas, pastebima sutrikusi audinių regeneracija dèl netinkamai kontroliuojamos užląstelinio užpildo baltymų apykaitos, lemiančios audinių struktūrinius ir funkcinius pokyčius [3]. Fibroblastai yra pagrindinès ląstelès, atsakingos už audinių regeneracijos procesus dèl kontraktilinių savybių bei gebejjimo gausiai gaminti užląstelinio užpildo baltymus [4].

Fibroblastus nuo kitų mezenchiminių ląstelių galima atskirti remiantis viduląsteline užląstelinio užpildo baltymų sudetimi - jie pasižymi specifinio baltymo vimentino raiška, netgi nesant kombinuotai sąveikai su desminu ir lygiųjų raumenų $\alpha$-aktinu. Aktyvuotuose fibroblastuose pastebima gausesnè viduląstelinè endoplazminio tinklo ir Goldžio komplekso raiška, o tai svarbu, nes šie organoidai dalyvauja užląstelinio užpildo baltymų - kolagenų, proteoglikanų, fibronektino bei atitinkamų proteazių, kurios šiuos baltymus ardo - sintezèje ir išskyrime [5].

\section{FIBROBLASTŲ TIPAI IR JŲ KILME்}

Fibroblastai yra mezenchiminès kilmès ląstelès. Organizme jų randama įvairių fenotipų - nuo nekontraktiliškų fibroblastų iki kontraktiliškumu bei didesniu aktyvumu pasižyminčių miofibroblastų su ịvairiais tarpiniais fenotipais [6]. Miofibroblastai atskiriami nuo kitų mezenchiminių ląstelių, tokių kaip lygiųjų raumenų ląstelès, vertinant specifinių žymenų - desmino ir lygiojo raumens miozino stygių, arba identifikuojant žymiai didesnę kitų diferenciacijos žymenų - lygiojo raumens $\alpha$-aktino ir fibronektino raišką. Naujausiais tyrimais įrodyta, kad fibroblastai diferencijuoja $\mathfrak{i}$ miofibroblastus pastebint visai naują baltymų raiškos modelị, kuris anksčiau, manyta, priklauso tik lygiųjų raumenų ląstelèms [7].

Miofibroblastai išsivysto transdiferencijuojant fibroblastams arba lygiųjų raumenų ląstelèms. Tačiau kol kas nepakankamai ištirta, ar miofibroblastų tipo ląstelès, kilusios iš fibroblastų ir lygiųjų raumenų ląstelių, pasižymi panašiomis arba skirtingomis populiacijos fenotipinèmis savybèmis. Taip pat neaišku, ar fibroblastai gali diferencijuoti ị lygiųjų raumenų ląsteles ir atvirkščiai, ar lygiųjų raumenų ląstelès gali diferencijuoti ị fibroblastus, aplenkiant miofibroblastų stadiją. Ilgą laiką vyravo nuomonè, kad fibroblastų, miofibroblastų populiacijos audiniuose susidarydavo ir atsinaujindavo tik proliferuojant jau esančioms motininèms ląstelèms. Per pastaruosius 10 metų pateikiama žymiai daugiau įrodymų, kad šios ląstelès, ypač vyraujant lètiniams audinių pažeidimams arba fibrotinems ligoms, audinyje gali atsirasti skirtingais būdais. Šie būdai apima epitelinị-mezenchiminị virsmą ir iš kaulų čiulpų bei audinių gaunamas mezenchimines kamienines ląsteles - fibrocitus (1 pav.).

\section{EPITELINIŲ LĄSTELIŲ VIRSMAS MEZENCHIMINĖMIS LĄSTELĖMIS}

Epitelinis-mezenchiminis virsmas yra procesas, kurio metu epitelinès ląstelès laipsniškai transformuojasi i̇ mezenchiminio tipo ląsteles, prarasdamos savo epitelinị funkcionalumą ir charakteristikas [8]. Šis procesas gali būti sutrikęs daugelio plaučių ligų metu, pvz., sergant obstrukcine plaučių liga ar plaučių vèžiu.

Manoma, kad epitelinis-mezenchiminis virsmas yra labai svarbus organizmui vystantis, tačiau žymiai suintensyvèja progresuojant vėžiui arba vyraujant uždegimui. Jo vaidmuo audinio atsake ị ịvairius epitelio sluoksnio pažeidimus ir stresą, kurie būdingi vyraujant lètiniam uždegimui, yra labai kontraversiškas bei susilaukia vis daugiau dèmesio tiriant plaučių ligas. Epitelinis-mezenchiminis virsmas reikalauja organizuotos epitelio ląstelių diferenciacijos, prarandant poliškumą, adhezines savybes ir glaudžiąsias jungtis dèl paviršiaus integrinų persigrupavimo bei nuslopintos atitinkamų baltymų ekspresijos, įskaitant 


\section{Moksliniai darbai}

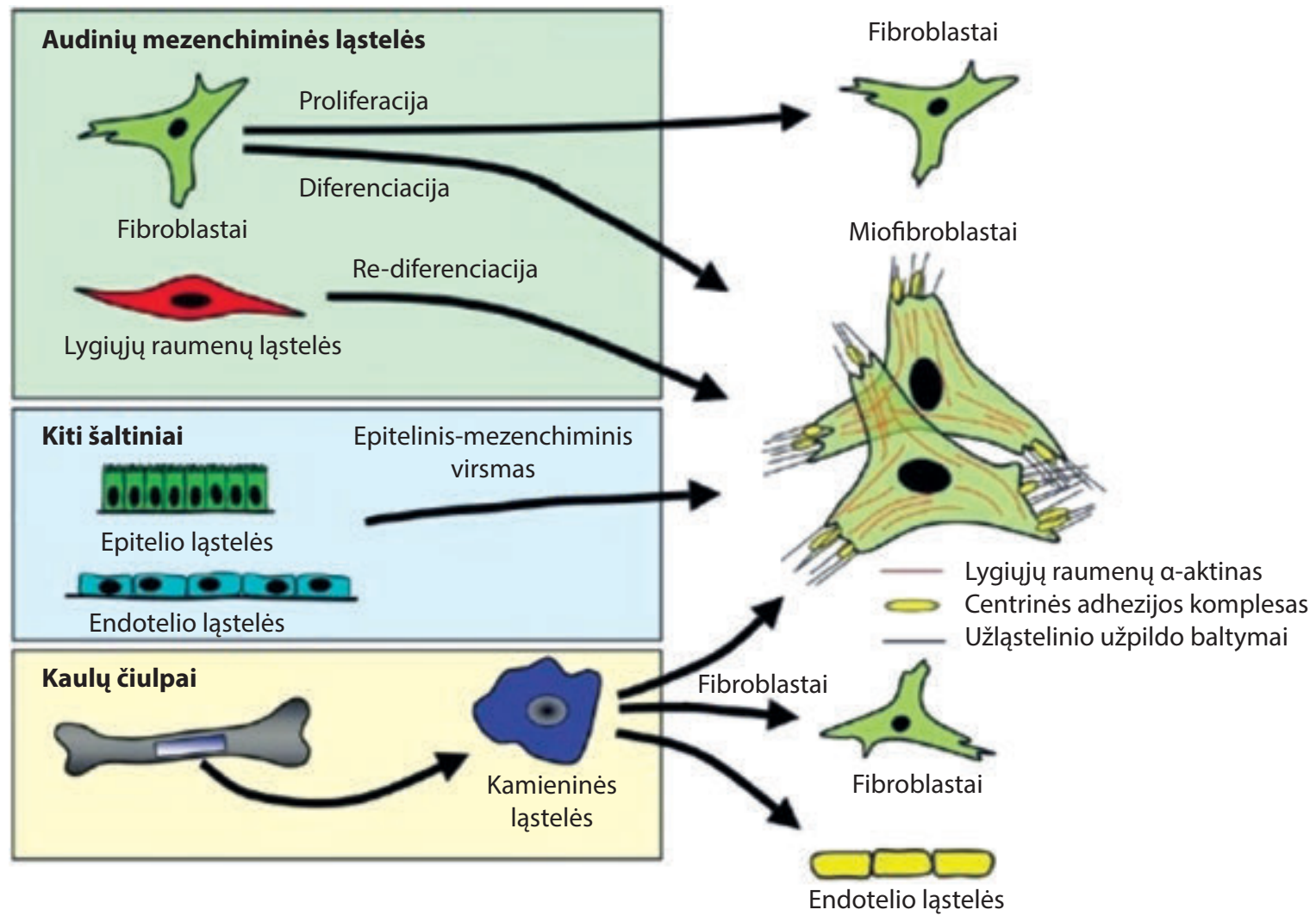

1 pav. Fibroblastų ir miofibroblastų kilmè audiniuose. Žmogaus organizme išskiriama keletas fibroblastų ir miofibroblastų šaltinių: 1) didžioji dalis fibroblastų diferencijuoja iš audiniuose esančių mezenchiminių kamieninių ląstelių; 2) lygiujų raumenų ląstelès gali rediferencijuoti ị fibroblastus; 3 ) epitelinès ląstelès gali diferencijuoti ị fibroblastus epitelinio-mezenchiminio virsmo metu; 4) dalis endotelinių ląstelių taip pat diferencijuoja i fibroblastus mažai ištirtu endotelinio-mezenchiminị virsmo keliu; 5) iš kaulų čiulpụ išskiriamos mezenchiminès kamieninès ląstelès - fibrocitai, kurie diferencijuoja ị fibroblastus po migracijos iš periferinio kraujo (pritaikyta remiantis Hinz ir kt. [6])

glaudžiųjų jungčių baltymą-1 $\left(\mathrm{ZO}_{1}\right)$, kadherinus ir desmoplakinus [9]. Šie procesai padeda išlaisvinti nepoliarizuotas epitelines ląsteles iš epitelio sluoksnio, turinčias pakitusi epiteliui būdingą kortikalinio citoskeletą į mezenchiminio tipo aktino streso pluoštu modelị. Nustatyta keletas medžiagų, skatinančių epitelinị-mezenchiminị virsmą: transformuojantis augimo faktorius $\beta$ (TGF- $\beta$ ), fibroblastų augimo faktorius-2 (FGF-2), epidermio augimo faktorius (EGF) ir insulino tipo augimo faktorius-II (IGF-II) [8, 10]. Ilgą laiką apie epitelinio-mezenchiminio virsmo egzistavimą buvo daug diskutuojama, nes įrodyti ši procesą in vitro yra sąlygininai lengva, tačiau in vivo sąlygomis gerokai sudètingiau. Lengviausias būdas tai padaryti - nustatyti viduląstelinių epitelinių ir mezenchiminiu žymenų pokyčius epiteliniame-mezenchiminiame virsme dalyvaujančiose ląstelèse. Šie žymenys gerai žinomi - labiausiai specifiniai yra epitelinès diferenciacijos žymenys: ZO-1, E-kadherinas, desmoplakinas, citokeratinas-18 ir MUC1, tuo tarpu fibroblastams būdingi žymenys, vimentinas, fibroblastams specifinis baltymas-1 (FSP1) ir lygiụjų raumenų a-aktinas yra mažiau specifiniai bei gali būti randami kitų tipų ląstelių populiacijose [11].
Kvejpavimo takų remodeliacija, sergant astma, pasižymi fibroblastų kaupimusi ir gausesne jų lokalizacija plaučiuose. Nors už tai atsakingi mechanizmai nèra pakankamai ištirti, epitelinis-mezenchiminis virsmas gali būti vienas iš tai lemiančių faktorių. Atlikti tyrimai parodè, kad pirminèse kvejpavimo takų epitelinių ląstelių kultūrose TGF- $\beta_{1}$ sukelia intensyvesni epitelinị-mezenchiminį virsmą, priklausomai nuo Smad signalinio kelio [9]. Tačiau iš sergančiųjų astma išskirtų pirminių kultūrų ląstelès patyre epitelinį-mezenchiminị virsmą greičiau už kontrolines, patvirtinant prielaidą, kad kvèpavimo takų epitelio sluoksnio reparacijos sistemos, sergant astma yra sutrikusios [9].

Kitas kvėpavimo takų remodeliacijos požymis yra sustorèjanti pamatinè membrana kartu su poepiteline fibroze bei epitelio sluoksnio irimas [12]. Normaliomis sąlygomis pažeistas epitelis gali greitai regeneruoti, tačiau lètinis uždegimas ir nuolatinè žala epiteliui, sergant astma, slopina sluoksnio regeneracines savybes. Tai sumažina epitelio ląstelių skaičių su paviršinemis blakstienèlemis, paliekant pamatinę membraną tik iš dalies padengtą bazinemis ląstelemis, kurios yra žymiai atsparesnès apoptozei. Lètinio uždegimo fone, sergant astma, reaguodami i 2 tipo T limfocitų pagal- 


\section{Moksliniai darbai}

bininkų išskiriamus mediatorius, eozinofilai išskiria didelius kiekius TGF- $\beta_{1}$, kuris skatina fibroblastų diferenciaciją į žymiai aktyvesnį miofibroblastų fenotipą su gausiai gaminamais užląstelinio užpildo baltymais. Viena labai svarbi užląstelinio užpildo baltymų savybių yra įvairių citokinų ir augimo faktorių kaupimas ir saugojimas, todèl TGF- $\beta_{1}$ gali būti kaupiamas plaučiu audiniuose bei, esant poreikiui, lokaliai išleidžiamas taip sukeliant epitelinį-mezenchiminị virsmą bei subepitelinę fibrozę [13]. Taip pat yra patikimų įrodymų, kad $\beta$-galaktozidazė, specifinis fibroblastų žymuo, yra specifiškai sintetinamas epitelinèse ląstelèse, įrodant ju diferenciaciją i fibroblastus, vystantis plaučių fibrozei, bei lemiant fibroblastų pagausèjimą plaučiuose. Taip iš dalies įrodama, kad epitelinis-mezenchiminis virsmas yra svarbus fibroblastų šaltinis plaučiuose [14].

\section{FIBROCITAI}

Fibrocitai - tai grupè mezenchiminių kamieninių ląstelių išskiriamų iš kaulų čiulpų, kurios pirmą kartą buvo identifikuotos $1994 \mathrm{~m}$. Tai ląstelès, turinčios hematopoetinių ląstelių, monocitų ir fibroblastų savybių. Jos laisvai cirkuliuoja periferiniame kraujyje ir migruoja ị atitinkamus regionus po audinių pažeidimo. Šios ląstelès yra unikalios, nes geba išskirti užląstelinio užpildo baltymus bei pasižymi hematopoeitinių ląstelių bei monocitų linijos žymenimis. Jų pagrindinis vaidmuo - tarnauti žaizdų gijimo procesuose, atliekant šias pagrindines funkcijas: išskirti įvairius citokinus, chemokinus ir augimo faktorius, sukuriant reparacijos procesui tinkamą aplinką; tarnauti kaip antigeną pristatančioms ląstelèms; padèti žaizdai užsiverti ir skatinti angiogenezę [15].

Periferiniame kraujyje cirkuliuojantys fibrocitai turi išreikštus hematopoetinių kamieninių ląstelių CD34, leukocitams būdingus CD45 žymenis bei keletą monocitams būdingų žymenų, tokių kaip CD11a/11b ir CD13/14a bei pasižymi gebejjimu išskirti pirmo tipo kolageną, fibronektiną ir vimentiną, o tai būdinga fibroblastams [16]. Daugiausia tyrimų rodo, kad fibrocitai subręsta iš $\mathrm{CD} 14^{+}$periferinio kraujo vienbranduolių ląstelių subpopuliacijos $[17,18]$, turinčios išreikštus Fc imunoglobulinus G (IgG), Fc $\gamma \mathrm{RI}$ (CD64) ir Fc $\gamma$ RII (CD32), bet neturi išreikštų Fc $\gamma$ RIII (CD64) [18-20].

Fibrocitų skaičius periferiniame kraujyje patikimai padideja sergantiesiems sunkia astma [21, 22]. Padidèjęs šių ląstelių skaičius pastebimas ir greta bronchų lygiųjų raumenų sluoksnio nepriklausomai nuo astmos sunkumo, bei jungiamajame audinyje - sunkios nekontroliuojamos astmos metu [22]. TGF- $\beta_{1}$, kurio kiekis sergančiųjų astma plaučiuose žymiai padidèja, gali priversti fibrocitus diferencijuoti ì miofibroblastus ir išskirti didelius kiekius užląstelinio užpildo baltymų, taip prisidedant prie kvėpavimo takų remodeliacijos vystymosi [21, 23]. Fibrocitų tipo ląstelių skaičius bei diferenciacija i kolageną išskiriančius miofibroblastus žymiai padidejja pacientų, sergančių astma, kvėpavimo takuose po provokacijos specifiniu alergenu [24]. Lengvos astmos metu nustatomas padidėjęs fibrocitų skaičius bronchų gleivinèje bei bronchoalveolinio lavažo skystyje, o subgleivinès fibrocitų skaičius koreliuoja su pamatinès membranos storiu [25]. Šią fibrocitų infiltraciją daugiausia lemia padidejęs endotelino-1 (ET-1) kiekis, kurị išskiria epitelio ir endotelio ląstelès bei padidejęs biologiškai aktyvaus TGF- $\beta_{1}$ kiekis iš epitelio ląstelių bei eozinofilų. Aktyvuota T limfocitų stadija bei didelè TGF- $\beta_{1}$ koncentracija audiniuose gali sukelti CD14+ diferenciaciją i fibrocitus [24, 26]. Kiti veiksniai, lemiantys fibrocitų infiltraciją yra kitų uždegiminių ląstelių išskiriami mediatoriai, tokie kaip Th2 limfocitų išskiriami interleukinai (IL)-4, 13 bei dendritinių ląstelių išskiriamas IL-1 $\beta$ [27].

\section{FIBROBLASTŲ VAIDMUO SERGANT ASTMA}

Fibroblastų invazija i kvépavimo takų pogleivio sluoksnius sergant astma yra vienas iš esminių kvèpavimo takų remodeliacijos požymių [28] (2 pav.). Po pažaidos arba aplinkos veiksnių poveikio fibroblastai migruoja ị subepitelinị regioną kvépavimo takuose, todèl jie dalyvauja žaizdos gijimo procese, valdant užląstelinio užpildo baltymų gamybą bei sąveiką su uždegiminèmis ląstelèmis [29]. Sergant astma, minètas žaizdų gijimo procesas bei remodeliacijos vystymasis kvėpavimo takuose sutrikdomas ir nevaldomas, taip lemiamas invazinių fibroblastų skaičiaus didejjimas bei subepitelinė fibrozè ir laikui bègant blogèjanti plaučių funkcija [30].

Sergant astma, pasikeičia kvėpavimo takų struktūra. Šie pokyčiai be kitų svarbių veiksnių, įeinančių i kvẻpavimo takų remodeliacijos sąvoką, apima ir užląstelinio užpildo kokybinius ir kiekybinius pokyčius bei padidèjusi miofibroblastų kieki jungiamajame audinyje. Kvépavimo takuose yra sudètingas makromolekuliu tinklas, kuris formuoja audinių "pastolius“. Šie pastoliai, tiksliau užląstelinis užpildas, yra labai svarbūs kvėpavimo takams, nes suteikia mechaninę paramą bei palaiko kvėpavimo takų struktūrą ir funkcijas [31]. Užląstelinis užpildas yra dinaminis ir kompleksinis tinklas, paveikiantis daugumą ląstelinių funkcijų, tokių kaip, migracija, diferenciacija arba proliferacija [32]. Taip pat jis gali sąveikauti su uždegiminèmis ląstelèmis, keisdamas jų aktyvumą, pasiskirstymą, išgyvenamumą ir adheziją. Taip pat gali reguliuoti skysčių pusiausvyrą, audinių elastingumą bei būti uždegiminių mediatorių ir augimo faktorių talpykla [32].

Plaučių fibroblastai tiesiogiai prisideda prie plaučių uždegimo ir kvėpavimo takų sienelių rekonstrukcijos. Šios ląstelès išskiria kelių rūšių junginius, kurie 


\section{Moksliniai darbai}

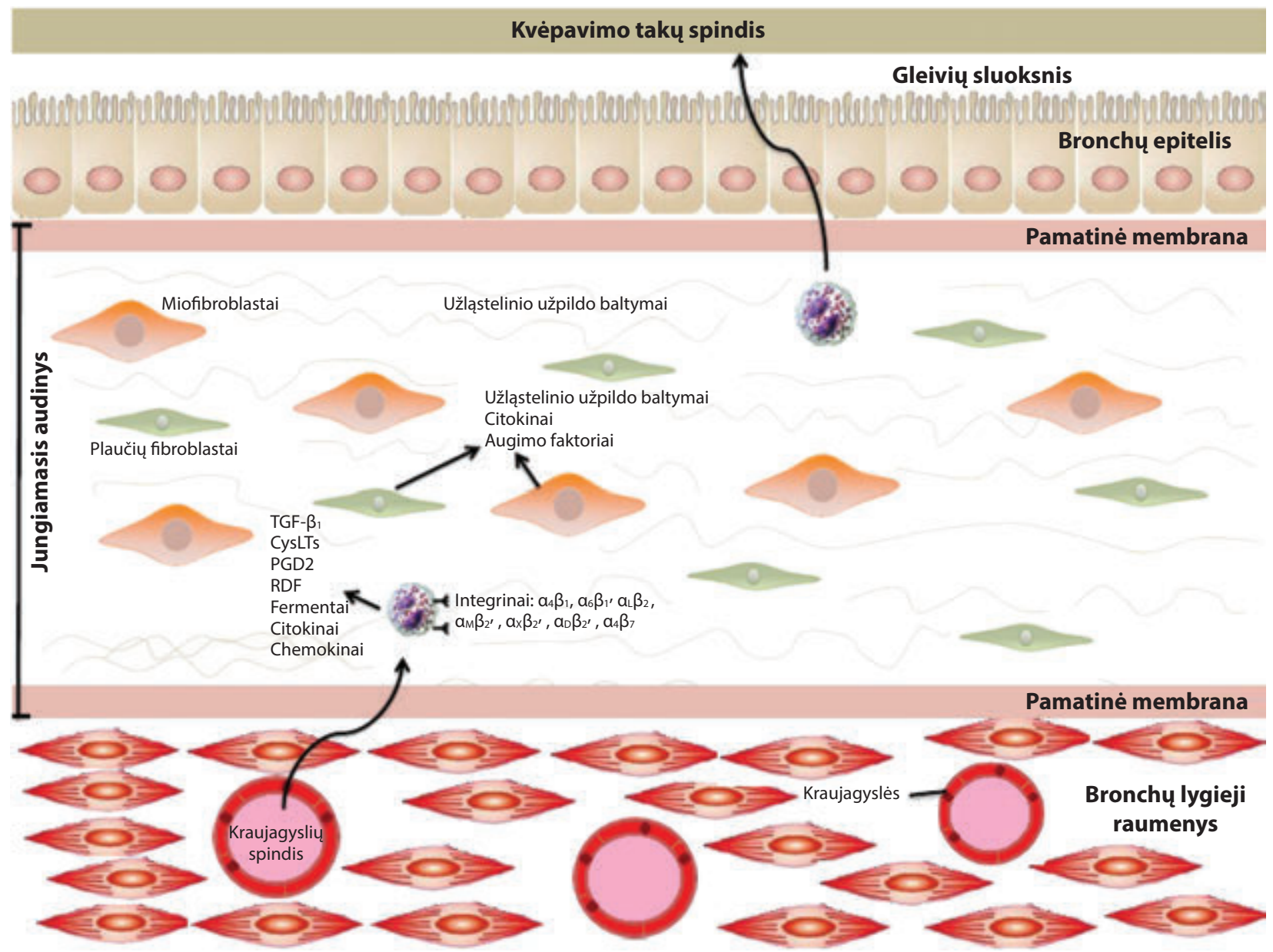

2 pav. Fibroblastų ir miofibroblastų sąveikos su uždegiminèmis ląstelèmis reikšmè jungiamojo audinio funkcijoms kvèpavimo takuose. Sergant astma, eozinofilų tiesioginè adhezija prie fibroblastų bei išskiriami citokinai, chemokinai ir augimo faktoriai skatina jų diferenciaciją i labiau aktyvų bei gausia užląstelinio užpildo baltymų gamyba pasižyminčių miofibroblastų fenotipą. Miofibroblastai lemia sutrikusią užląstelinio užpildo apykaitą jungiamajame audinyje bei subepitelinès fibrozès vystymąsi sergant astma.

turi didelị poveikị supančiai aplinkai. Fibroblastai yra pagrindinis I ir III tipo kolagenų ląstelinis šaltinis, reguliuojamas IL- $1 \beta$ bei TGF- $\beta$, kurie skatina prokolageno geno raišką. Priešingai, kiti fibroblastų išskirti ir suaktyvinti citokinai, pvz., IL-6 sukelia atvirkštinị poveikị. Jie skatina fibroblastus išskirti matrikso metaloproteinazę (MMP)-2 (kolagenazę) ir MMP-9 (gelatinazę), kurios sukelia užląstelinio užpildo remodeliaciją. Tokiu būdu citokinas IL-1 $\beta$ skatina užląstelinio užpildo nusèdimą dèl kolageno sintezès, o IL-6 šeima prisideda prie užląstelinio užpildo remodeliacijos dèl MMP gamybos ir matrikso baltymų irimo [33].

Apibendrinus galima teigti, kad fibroblastai dèl savo unikalių biologinių ir biomechaninių savybių yra svarbus tyrimo objektas ịvairių patologijų, ịskaitant ir astmą, metu. Sergant astma metu lètinio kvẻpavimo takų uždegimo metu išskiriami mediatoriai sukelia fibroblastų aktyvaciją. Nors astma neišgydoma liga, tinkamas jos valdymas žymiai pagerina pacientu gyvenimo kokybę, todèl tolesni tyrimai, įtraukiant fibroblastus, gali padèti atrasti naujus, dar netaikomus būdus, padèsiančius valdyti kvèpavimo takų remodeliacijos vystymąsi sergant astma.

Gauta 20170820

Priimta 20170921

\section{LITERATŪRA}

1. McAnulty RJ. Fibroblasts and myofibroblasts: their source, function and role in disease. The international journal of biochemistry \& cell biology. 2007;39(4):666-71.

2. Thiery JP, Acloque H, Huang RY, Nieto MA. Epithelialmesenchymal transitions in development and disease. cell. 2009;139(5):871-90.

3. Olczyk P, Mencner $\mathbf{L}$, Komosinska-Vassev K. The role of the extracellular matrix components in cutaneous wound healing. BioMed research international. 2014;2014.

4. Gurtner GC, Werner S, Barrandon Y, Longaker MT. Wound repair and regeneration. Nature. 2008;453(7193):314.

5. Frantz C, Stewart KM, Weaver VM. The extracellular matrix at a glance. Journal of Cell Science. 2010;123(24):4195-200.

6. Hinz B, Phan SH, Thannickal VJ, Galli A, Bochaton-Piallat M-L, Gabbiani G. The myofibroblast: one function, multiple origins. The American journal of pathology. 2007;170(6):1807-16.

7. Klingberg F, Hinz B, White ES. The myofibroblast matrix: implications for tissue repair and fibrosis. The Journal of pathology. 2013;229(2):298-309. 


\section{Moksliniai darbai}

8. Kalluri R, Weinberg RA. The basics of epithelial-mesenchymal transition. The Journal of clinical investigation. 2009;119(6):1420.

9. Hackett T-L, Warner SM, Stefanowicz D, Shaheen F, Pechkovsky DV, Murray LA, et al. Induction of epithelialmesenchymal transition in primary airway epithelial cells from patients with asthma by transforming growth factor- $\beta 1$. American journal of respiratory and critical care medicine. 2009;180(2):122-33.

10. Willis BC, Borok Z. TGF- $\beta$-induced EMT: mechanisms and implications for fibrotic lung disease. American Journa of Physiology-Lung Cellular and Molecular Physiology. 2007;293(3):L525-L34.

11. Mani SA, Guo W, Liao M-J, Eaton EN, Ayyanan A, Zhou AY, et al. The epithelial-mesenchymal transition generates cells with properties of stem cells. Cell. 2008;133(4):704-15.

12. Trejo Bittar HE, Yousem SA, Wenzel SE. Pathobiology of severe asthma. Annual Review of Pathology: Mechanisms of Disease. 2015;10:511-45.

13. Hackett T, Warner S, Shaheen F, Pechkovsky D, Argenteri R, Murray L, et al. TGF-beta-induces epithelial-mesenchymaltransition in primary human bronchial epithelial cells from normal and asthmatic subjects. American Journal of Respiratory and Critical Care Medicine. 2008;177:A97.

14. Johnson JR, Roos A, Berg T, Nord M, Fuxe J. Chronic respiratory aeroallergen exposure in mice induces epithelial-mesenchymal transition in the large airways. PloS one 2011;6(1):e16175.

15. Bellini A, Mattoli S. The role of the fibrocyte, a bone marrowderived mesenchymal progenitor, in reactive and reparative fibroses. Laboratory investigation. 2007;87(9):858.

16. Bucala R, Spiegel L, Chesney J, Hogan M, Cerami A. Circulating fibrocytes define a new leukocyte subpopulation that mediates tissue repair. Molecular medicine. 1994;1(1):71.

17. Varcoe R, Mikhail M, Guiffre A, Pennings G, Vicaretti M, Hawthorne W, et al. The role of the fibrocyte in intimal hyperplasia. Journal of Thrombosis and Haemostasis. 2006;4(5):1125-33.

18. Pilling D, Tucker NM, Gomer RH. Aggregated IgG inhibits the differentiation of human fibrocytes. Journal of leukocyte biology. 2006;79(6):1242-51.

19. Haudek SB, Xia Y, Huebener P, Lee JM, Carlson S, Crawford JR, et al. Bone marrow-derived fibroblast precursors mediate ischemic cardiomyopathy in mice. Proceedings of the National Academy of Sciences. 2006;103(48):18284-9.

20. Pilling D, Buckley CD, Salmon M, Gomer RH. Inhibition of fibrocyte differentiation by serum amyloid P. The Journal of Immunology. 2003;171(10):5537-46.

21. Wang C-H, Huang C-D, Lin H-C, Lee K-Y, Lin S-M, Liu C-Y, et al. Increased circulating fibrocytes in asthma with chronic airflow obstruction. American journal of respiratory and critical care medicine. 2008;178(6):583-91.

22. Saunders R, Siddiqui S, Kaur D, Doe C, Sutcliffe A, Hollins F, et al. Fibrocyte localization to the airway smooth muscle is a feature of asthma. Journal of Allergy and Clinical Immunology. 2009;123(2):376-84

23. Abe R, Donnelly SC, Peng T, Bucala R, Metz CN. Peripheral blood fibrocytes: differentiation pathway and migration to wound sites. The Journal of Immunology. 2001;166(12):7556-62.

24. Schmidt M, Sun G, Stacey MA, Mori L, Mattoli S. Identification of circulating fibrocytes as precursors of bronchial myofibroblasts in asthma. The Journal of Immunology. 2003;171(1):380-9.

25. Nihlberg K, Larsen $K$, Hultgårdh-Nilsson A, Malmström A, Bjermer L, Westergren-Thorsson G. Tissue fibrocytes in patients with mild asthma: a possible link to thickness of reticular basement membrane? Respiratory research. 2006;7(1):50.

26. Wada T, Sakai N, Matsushima K, Kaneko S. Fibrocytes: a new insight into kidney fibrosis. Kidney international. 2007;72(3):269-73.

27. Bousquet J, Jeffery PK, Busse WW, Johnson M, Vignola AM Asthma: from bronchoconstriction to airways inflammation and remodeling. American journal of respiratory and critical care medicine. 2000;161(5):1720-45.

28. Benayoun L, Druilhe A, Dombret M-C, Aubier M, Pretolani M. Airway structural alterations selectively associated with severe asthma. American journal of respiratory and critical care medicine. 2003;167(10):1360-8.

29. Crosby LM, Waters CM. Epithelial repair mechanisms in the lung. American Journal of Physiology-Lung Cellular and Molecular Physiology. 2010;298(6):L715-L31.

30. Holgate ST, Davies DE, Lackie PM, Wilson SJ, Puddicombe SM, Lordan JL. Epithelial-mesenchymal interactions in the pathogenesis of asthma. Journal of Allergy and Clinical Immunology. 2000;105(2):193-204.

31. Badylak SF. The extracellular matrix as a biologic scaffold material. Biomaterials. 2007;28(25):3587-93.

32. Hay ED. Cell biology of extracellular matrix: Springer Science \& Business Media; 2013

33. Knight D. Epithelium-fibroblast interactions in response to airway inflammation. Immunology and cell biology. 2001;79(2):160. 